\title{
We should count ourselves lucky
}

\author{
C. Sandler ${ }^{1}$
}

In brief

Last summer I was extremely lucky to have the opportunity to visit Harvard School of Dental Medicine for my elective. I now return to my final year of dental school in Manchester with a renewed sense of appreciation for the education system I have entered in to. I was shocked at the price dental students in America pay to receive an education, and at some of their unusual practices along the way.

After having had the opportunity to visit Harvard Dental School I have returned to the UK with a newfound appreciation for the education system I am in as a final year dental student in Manchester. I can see so many advantages of studying over in America, however, I cannot work out how normal students manage to fund their education.

For any student in America to get into a dental school they must first attend four years of college where they will study a wide range of subjects. They can choose a mixture of science and arts subjects, but must have the basic sciences to apply to dental school. The requirements change from school to school but for most require a year of biology, chemistry, organic chemistry, physics and maths, among other subjects. College students in America can expect to pay an average of $\$ 19,000$ tuition fees per year, which comes to a grand total of $\$ 76,000$ of debt, and that is before they have even started dental school. ${ }^{1}$

To gain acceptance into a dental school they must graduate from college with top grades and also score well in the Dental Aptitude Test (DAT) which is conducted by the American

'University of Manchester, Dental School, J R Moore Building, Oxford Road, Manchester, M13 9PL

*Correspondence to: Cara Sandler

Email: sandler.cara@gmail.com

Refereed Paper. Accepted 22 November 2016

DOI: 10.1038/sj.bdj.2017.164

${ }^{\odot B r i t i s h ~ D e n t a l ~ J o u r n a l ~ 2017 ; ~ 222: ~ 243-244 ~}$
Dental Association. The DAT is designed to measure general academic ability, comprehension of scientific information, and perceptual ability. ${ }^{2}$ Students must score extremely highly in their college subjects and the DAT to be accepted into dental school. The DAT costs $\$ 400$, along with an Associated American Dental Schools Application Service fee of $\$ 245$. This is the cost of simply applying to one dental school and they must pay an additional fee of $\$ 93$ for each additional school they want to apply to.

These are minor costs in comparison to the tuition fees, but one blog that I came across advising students on dental school applications recommends that 'weaker applicants' should be applying to at least 10-15 different schools. If selecting a more prestigious institution, such as Harvard, and applying from out of state, then the annual cost of tuition is $\$ 55,850 .{ }^{4}$ Most dental programmes in America last four years which results in just over $\$ 223,000$ additional debt, just for the tuition, to obtain a DDS or DMD qualification.

If, like me, you were in the lucky year that entered into a UK university before the astronomic increase in tuition fees, then your BDS qualification will have cost $£ 3,000$ per year tuition fees, totalling $£ 15,000$ debt once graduated. This converts to roughly $\$ 20,000$, not even $10 \%$ of the debt accrued by our US equivalents. Those who have entered a UK dental school after the rise in tuition fees will be looking at more like $£ 45,000$ debt, (approx $\$ 60,000$ ) for tuition; still only a quarter of what our American counterparts can expect to be burdened with.

Harvard School of Dental Medicine admits 35 students per year. A small number compared to most UK dental schools, which have between 65 and 100 students per year, although numbers are said to be to be decreasing due to reduced government funding. The majority of Harvard students will apply straight to speciality training from dental school without spending anytime in general practice.

Their speciality training is by far the most expensive part of their education with fees around $\$ 58,000^{5}$ per year - a three-year course totalling $\$ 174,000$ in tuition fees (Table 1). These figures are purely the costs of tuition, and they of course incur the extra expenses

Table 1 US dental education tuition fees

\begin{tabular}{l|l|l} 
& Tuition fee per year (\$) & Total tuition fees (\$) \\
\hline College & 18,943 & 75,772 \\
\hline Dental school & 55,850 & 223,400 \\
\hline Specialist training & 58,050 & 174,150 \\
\hline Total & & $\mathbf{4 7 3 , 3 2 2}$ \\
\hline
\end{tabular}


of disability and malpractice insurance, books and supplies, room, board, travel, personal expenses and loan fees.

First year orthodontic residents that I met at Harvard explained the process of applying for specialist training in America, and I was once again surprised at the cost. Each of the four students had applied to between 10 and 20 different orthodontic schools for specialist training. Each school had an application fee of roughly $\$ 80-\$ 150$. In addition to this, the application website (through which applications are sent electronically) charged about $\$ 100$ per school. Almost every school required official board scores to be sent, which cost $\$ 36$ per individual application. For schools that required the GRE, an admissions test of verbal and quantitative reasoning and analytical writing, the cost was $\$ 25$ per school. Also some programmes require the applicant to send college transcripts, which costs between $\$ 10-\$ 20$ per school. That comes to a cost of between \$250-\$330 per application for each school, amounting to a grand total of $\$ 6,600$, if, like the residents who I met, one is applying to 20 different schools.

It was pointed out to me that the students who don't come 'top of the class' in dental school must apply to more places for specialist training as they are less likely to be accepted to their first few choices. The financial cost of poor grades must be an incentive to work hard, although I was also told of students who were near the top of their class and were natural worriers so they applied to many more schools than they probably needed to. To top it all, the schools that like a particular application will invariably offer the candidate an interview, but they will only contact the candidate very close to the interview date, necessitating the purchase of expensive flights and accommodation at the last minute.

I was also shocked that most medical insurance in America does not cover basic dental care and must be paid for in a separate policy. One of the ways that we are able to have such high quality teaching in UK dental schools is because we can offer absolutely free treatment to all our patients, whereas dental schools in the US offered patients treatment at a 'reduced cost' only, rather than for free. This means that students may desperately need to carry out certain treatments to meet their clinical requirements for graduation, but patients are unable to pay for the work needed. This can lead to students paying for the lab work which may cost up to $\$ 600$ for a crown. Additionally, at some schools the patients have requested that students consider paying them for 'their time. As we all know student appointments can be time consuming and time is money, so students would end up paying their patients up to $\$ 150$ just to attend appointments to compensate for their loss of earnings for half a day. I hope this completely unacceptable practice doesn't ever reach the UK.

I assume that the UK system is fairer and therefore much more accessible to students from a wide variety of backgrounds, who may not be able to even consider the same career choice in the USA.

1. Bridgestock L. How much does it cost to study in the US? 2016. Available online at http://www.topuniversities.com/student-info/student-finance/how-much-doesit-cost-study-us (accessed January 2017).

2. American Dental Association. Dental Admission Test (DAT) 2017 Program GuideProgram Guide. Available online at http://www.ada.org/ /media/ADA/Education\%20and\%20Careers/Files/dat_examinee_guide. ashx (accessed January 2017).

3. SDN. Scumbag Steve's Ultimate Guide to the 2017 Application Cycle (and the universe). 2016. Available online at https://forums.studentdoctor.net/threads/ scumbag-steves-ultimate-guide-to-the-2017-application-cycle-and-the-universe.1197114/ (accessed January 2016).

4. Startclass. Harvard University School of Dental Medicine. Available online at http://dental-schools. startclass.com///26/Harvard-University-School-of-Dental-Medicine (accessed January 2017).

5. Harvard School of Dental Medicine. Harvard School of Dental Medicine, Orthodontics, Cost of Attendance, 2016-2017. Available online at http://hsdm. harvard.edu/files/dental/files/ortho_budget_16-17.pdf (accessed January 2017). 